\title{
Editorial
}

\section{Paul Brown}

Professor, Department of Materials Science and Engineering, Pennsylvania State University, USA

The topical content of this issue of Advances in Cement Research reflects the broadness of various aspects of cement-based civil engineering materials. Papers are directed towards cement production, non-Portland based cements, mineral and non-mineral admixtures and environmental issues.

Hökfors et al. (2014) describe modelling the cement process and cement clinker quality. The atmosphere within a kiln strongly influences the energy efficiency with which $\mathrm{CO}_{2}$ is abstracted from $\mathrm{CaCO}_{3}$. Insufficient oxygen does not permit optimal fuel combustion. The presence of excessive air reduces thermal efficiency because of the heat capacity requirements of nonreactive gases. This paper models the benefits of oxygen enrichment in terms of clinker chemistry, rate of clinker production and energy consumption. The model indicated that oxygen enrichment to $95 \%$ increased the rate of clinker production by $17 \cdot 5 \%$ and reduced energy requirement by $11.8 \%$ when compared to control conditions. Other benefits cited in the paper include the theoretical ability to use a broader range of fuel sources.

Effect of gauging solution densities on magnesia cement is reported on by Yadav and Gupta (2014). Unlike Portland cements, some cementing compounds can be produced using reactants which have true solubilities. Among these is magnesium oxychloride (Sorel's) cement where the binding solid is formed by the reaction between particulate $\mathrm{MgO}$ and a solution of $\mathrm{MgCl}_{2} \cdot 6 \mathrm{H}_{2} \mathrm{O}$. The effects of solution density (viscosity) on property development were systematically examined. As the solution density increased to saturation, both the times of initial and final set were observed to increase. The effects of $\mathrm{MgCl}_{2} \cdot 6 \mathrm{H}_{2} \mathrm{O}$ solution viscosity on consistency were examined and only minimal increases in solution volume were required to retain constant consistency. Measurements of dimensional changes when samples cured for 7 days were immersed in boiling water and then removed from boiling water indicated that dimensional stability increased with increases in solution density. Compressive strengths of paste cubes cured for 30 days increased with increasing solution density with the exception of the cube strength obtained when the $\mathrm{MgCl}_{2} \cdot 6 \mathrm{H}_{2} \mathrm{O}$ solution was saturated. This produced the lowest strength observed and was interpreted to be a consequence of the inability to attain appropriate homogenisation. This systematic study reveals the importance of the proportioning as it affects property development in Sorel cement.

Trauchessec et al. (2014) have studied the impact of anhydrite proportion in a calcium sulfoaluminate cement and Portland cement blend. The hydration of $\mathrm{C}_{4} \mathrm{~A}_{3} \hat{\mathrm{S}}$ to form ettringite requires an additional source of sulfate. The retardation of the hydration of Portland cement also requires the presence of a source of sulfate. Although anhydrous calcium sulfate (anhydrite) serves both requirements, the optimal proportions are greatly different. This creates a significant challenge if it is desired to produce cements which are blends of sulfoaluminate and Portland cements. The reactions that produce ettringite from sulfoaluminate must reach nominal completion with respect to the consumption of anhydrite to preclude significant continued ettringite formation as a result of the hydration of $\mathrm{C}_{3} \mathrm{~A}$ from Portland cement. If this criterion is not met, then the blend will exhibit dimensional instability. The parameters of optimisation were established in this study by evaluating the dimensional stabilities, compressive strengths and heat evolution characteristics of mortar blends as a function of the proportion of anhydrite in the blends.

The influence of mineral admixtures on strength and hydration products of lime-activated slag cement has been evaluated by Murmu and Singh (2014). Establishing the behaviour of byproducts when used as cements remains an active area of research. This includes studies of lime activated slags. The present study explored the strength gain characteristics of slag activated by lime and plaster of Paris. Strengths of mortars incorporating silica fume, fly ash, ground glass and Portland cement as admixtures were determined. In addition to strength determination, hydration was followed by determining pore size distribution and by establishing phase evolution using X-ray diffraction analyses and differential thermal analyses.

Østnor and Justnes (2014) have considered durability of mortar with calcined marl as supplementary cementing material. Due to the extensive release of $\mathrm{CO}_{2}$ in cement production, there is benefit in the partial replacement of Portland cement by pozzolans. Marl is a mixture in which about $20 \%$ of the calcium carbonate is finely dispersed among clay minerals. When calcined, marl exhibits pozzolanic properties. The effects of cement replacements of up to $65 \%$ by calcined marl were established. As would be expected, an early strength reduction was observed regardless of replacement level. However, 20 and 35\% replacement levels resulted in compressive strengths higher than that of the control at all ages past 7 days. In addition to compressive strength determinations, the effects on a variety of other parameters were examined as a function of replacement level. These included flexural strength, capillary suction, expansion with sulfate exposure, carbonation depth and electrical resistivity 
determinations. The paper provides a very useful overview of the influence of calcined marl pozzolan on property development.

Enrichment of compressive strength in microbial cement mortar is proposed by Senthilkumar et al. (2014). Based on the expectation that bacterial metabolism would generate carbonate thereby facilitating the precipitation of calcium carbonate, bacteriacontaining aqueous nutrient media were used as mixing solutions to produce mortar samples. The paper claims that aragonite, vaterite and calcite had all formed within the pore structures of the mortars produced. The compressive strength determinations cited, reported as much as a $44 \%$ increase in compressive strength. Sorption test results indicated significant reduction in water uptake by samples constituted using bacteria-containing solutions.

Baltakys et al. (2014) studied the effect of gyrolite substituted with cadmium ions on the hydration kinetics of OPC at early stages. Since their solubility minima tend to be at elevated $\mathrm{pH}$ values, a cement pore solution provides an attractive environment in which hydroxides of toxic elements can be sequestered. Gyrolite, a hydrated calcium silicate having a $\mathrm{C}: \mathrm{S}$ ratio of $2: 3$, was prepared under hydrothermal conditions and was then exposed to an aqueous cadmium containing solution. The extent of Cd uptake was established. After drying, the Cd substituted gyrolite was used as a partial replacement for cement at levels up to $7 \cdot 5 \%$. The effects of gryolite on hydration and the extent of $\mathrm{Cd}$ sequestration were determined. While gyrolite accelerated early hydration, its presence had little effect on overall hydration. The study revealed that $\mathrm{Cd}$ could be effectively sequestered within a cementitious host.

\section{REFERENCES}

Baltakys K, Eisinas A and Siauciunas R (2014) The effect of gyrolite substituted with cadmium ions on the hydration kinetics of OPC at early stages. Advances in Cement Research 26(6): 361-370, http://dx.doi.org/10.1680/ adcr.13.00048.

Hökfors B, Eriksson M and Viggh E (2014) Modelling the cement process and cement clinker quality. Advances in Cement Research 26(6): 311-318, http://dx.doi.org/10.1680/ adcr.13.00050.

Murmu M and Singh SP (2014) Influence of mineral admixtures on strength and hydration products of lime-activated slag cement. Advances in Cement Research 26(6): 334-343, http://dx.doi.org/10.1680/adcr.13.00042.

Østnor TA and Justnes H (2014) Durability of mortar with calcined marl as supplementary cementing material. Advances in Cement Research 26(6): 344-352, http://dx.doi.org/10.1680/adcr.13.00040.

Senthilkumar V, Palanisamy T and Vijayakumar VN (2014) Enrichment of compressive strength in microbial cement mortar. Advances in Cement Research 26(6): 353-360, http://dx.doi.org/10.1680/adcr.13.00053.

Trauchessec R, Mechling J-M, Lecomte A, Roux A and Le Rolland $B$ (2014) Impact of anhydrite proportion in a calcium sulfoaluminate cement and Portland cement blend. Advances in Cement Research 26(6): 325-333, http://dx.doi.org/ 10.1680/adcr.13.00051.

Yadav RN and Gupta P (2014) Effect of gauging solution densities on magnesia cement. Advances in Cement Research 26(6): 319-324, http://dx.doi.org/10.1680/adcr.13.00036. 